\title{
Properties of Cellular Concrete for Filters
}

\author{
Renato César Maruyama and Gladis Camarini
}

\begin{abstract}
Considering the trends of new materials in Construction, the lightweight concrete with a density between 400 and $1800 \mathrm{~kg} / \mathrm{m}^{3}$ has been the subject of several studies with emphasis on particle size distribution of aggregates and their raw materials. Some of the advantages of cellular concrete are its lightness, resistance to freezing and thawing, good thermal insulation and acoustics. It can be used as blocks, precast masonry panels, filling and regularization of slabs to be waterproofed. The aim of this work is to study the material proportion that composes the cellular concrete, such as cement, sand, admixtures and water. It was analyzed the composite in the fresh and hardened state. Properties, such as compressive strength, water permeability of the plates, water absorption by immersion and by capillary rise were determined. The tests followed the Brazilian Standards and took place in cylindrical, prismatic and cubic specimens. It was made seven mixtures with four different admixtures, TecFoam, TecFill, CO 436 and Less S. The cellular concrete with TecFoam and Less S obtained strength and porosity for filtering water.
\end{abstract}

Index Terms-Cellular foam concrete, mechanical properties, porosity, water absorption, water permeability.

\section{INTRODUCTION}

According to Chandra [1], the lightweight concrete has its roots in the ancient period of about 3000 years ago, when volcanic ash was used as fine aggregate. Since then, the concrete study is rapidly evolving with new tools, such as scanning electron microscopy and new materials. It has enabled more comprehensive knowledge, plus the strength and durability of concrete.

An example of the developments in the study of concrete is the cellular concrete. This lightweight concrete has many pores, having diameters ranging from $0.01 \mathrm{~mm}$ to $1 \mathrm{~mm}$, uniformly distributed in the cement paste. The honeycomb structure is obtained by stable incorporation of air bubbles in the cement paste by stirring admixture and water. When this air comes out of the concrete, it leaves voids in its matrix. Allende [2] studied that the voids ensure the concrete not only lightweight, but also incombustibility, excellent resistance to freezing and thawing, and good thermal and acoustic insulation.

Although it is called "concrete", cellular foam concrete has not coarse aggregate in its composition. According to

Manuscript received April 5, 2014; revised June 28, 2014. This work was supported by São Paulo Research Foundation (FAPESP - No121810) and by the National Counsel of Technological and Scientific Development - CNPq.

Renato César Maruyama is with the Construction Materials Laboratory at University of Campinas, UNICAMP. Campinas, São Paulo Brazil (e-mail: renatomaruyama23@gmail.com).

Gladis Camarini is with the School of Civil Engineering and Urban Design at University of Campinas, UNICAMP. Campinas, São Paulo, Brazil, Av. Albert Einstein, 951, POBox 6021, CEP: 13083-852, Campinas, SP, Brazil (e-mail: gcamarini@gmail.com, camarini@fec.unicamp.br).
Narayanan [3], it is considered a special type of mortar and homogeneous compared to conventional concrete. It can be classified for the type of binder, cement or lime, or the method of curing, autoclaved or not.

According to Teixeira Santos [4], cellular concrete can be produced by foaming agents or chemical aeration. The first is called cellular foam concrete because it is made with the addition of a pre-formed foam or a foam generated by the mixer. For Narayanan et al., [3], the chemical aeration is the most used and the foam is added during the paste phase of concrete. The air, which was introduced into the paste, leaves the concrete, forming pores in its matrix. By having a low density, cellular concrete can be produced in basic operating conditions, requiring no special equipment (except for the foam generator) or skilled labor. It is self-leveling, no need for vibration and healing is done under normal atmospheric conditions.

According to Allende [2], the final product shows strength compatible with their use as lightweight concrete, such as blocks, precast masonry panels, filling and regularization of slabs to be waterproofed. According to Legastski [5], it also can be used as thermal and acoustic insulation, firewall, and rehabilitation of old buildings floors, bases of highway, airports and railways. Furthermore, it is a workaround in the Geotechnical area, because it can replace or strengthen the poor soils. According to Rossignolo et al., [6], the lightweight concrete allows the reduction of the density, with the maintenance of mechanical resistance, leading to a reduction of own weight and loads acting on the foundation.

According to Neville [7], there is almost a linear relationship between the thermal conductivity and density of lightweight concrete made with different types of light aggregates. Loudon [8] concluded that despite the effects of the different aggregates used, the thermal conductivity of the lightweight concrete decreases as density decreases.

Demirboga et al., [9] investigated the thermal conductivity and compressive strength of expanded perlite aggregate concrete with mineral admixtures. They concluded that silica fume and fly ash as a cement replacement can decrease thermal conductivity by $15 \%$. The density and compressive strength are also reduced to $30 \%$. Liu et al., [10] developed a lightweight aggregate concrete with high resistance to penetration of water and chloride ions. The results were the cement content $500 \mathrm{~kg} / \mathrm{m}^{3}$ and unit density of $1400 \mathrm{~kg} / \mathrm{m}^{3}$ by applying expanded clay and expanded glass.

The use of cellular concrete in Brazil began in the early 70s. However, its properties were studied later by Ferreira [11] and the experimental study was made by Teixeira Filho [4]. He added the sand in the cellular concrete matrix, obtaining improvements in mechanical properties, especially in the compressive strength in accordance with the increase in density. Freitas et al., [12] analyzed the influence of two 
different admixtures (organic and inorganic) in the production and in the strength of cellular concrete with sand and lightweight aggregate. The same authors [13] also analyzed the cellular concrete mixtures for the volume production and the variation of mechanical properties of cellular concrete produced with the addition of sand and expanded clay.

The aim of this experimental work is to obtain a product with adequate strength and porosity suitable for the production of boards to be used for filtering water.

\section{EXPERIMENTAL PROCEDURE}

\section{A. Materials}

Natural river sand of particle size lower than $1.2 \mathrm{~mm}$ was used. All tests with the sand followed the Brazilian Standards [14]-[17]. The sand had: fineness modulus of 1.14, maximum diameter of $1.2 \mathrm{~mm}$, specific gravity of $2620 \mathrm{~kg} / \mathrm{m}^{3}$ and bulk unit weight of $1410 \mathrm{~kg} / \mathrm{m}^{3}$. It was used a High Initial Stength Portland cement (named CPV-ARI)

The admixtures used were RheoSet TecFill and RheoSet TecFoam, by Grace Company; and Rhodapex Less S and Rhodapex CO 436, made by Rhodia Poliamida Especialidades Ltda.

For the RheoSet TecFill admixture, it is recommended initial dosage of $100 \mathrm{~mL}$ for each $1000 \mathrm{~L}$ of concrete or mortar For RheoSet TecFoam, it is recommended $0.5 \%$ by mass of cement. Rhodapex Less S and Rhodapex CO 436 admixtures used $1 \%$ by the amount of mixing water.

\section{B. Experimental Mixtures}

Table I shows the mix design of each mixture for the production of cellular concrete.

In the mixture 2 , it was added $10 \mathrm{~g}$ of admixture in the form of foam, which was mixed in $100 \mathrm{~mL}$ of water. In mixture 3 , it was used $20 \mathrm{~g}$ of detergent in order to analyze its behavior in combination with the admixture.

TABLE I: COMPOSITION OF MORTAR MIXTURES AND ADMIXTURES FOR PRODUCTION OF CELlULAR CONCRETE

\begin{tabular}{cccccccc}
\hline \hline Mixtures & 1 & 2 & 3 & 4 & 5 & 6 & 7 \\
\hline \hline Materials & & & & & & & \\
\hline Cement $(\mathrm{kg})$ & 4.00 & 4.00 & 4.00 & 4.00 & 4.00 & 4.00 & 4.00 \\
\hline Sand $(\mathrm{kg})$ & 2.85 & 2.85 & 2.85 & 2.85 & 2.85 & 2.85 & 2.85 \\
\hline Water $(\mathrm{kg})$ & 1.10 & 1.10 & 1.30 & 1.60 & 1.60 & 1.60 & 1.60 \\
\hline TecFoam $(\mathrm{g})$ & 120 & - & 50 & 40 & - & - & - \\
\hline TecFill $(\mathrm{g})$ & - & - & - & - & 40 & - & - \\
\hline Less S $(\mathrm{g})$ & - & 20 & - & - & - & - & 40 \\
\hline CO 436 $(\mathrm{g})$ & - & - & - & - & - & 40 & - \\
\hline \hline
\end{tabular}

All materials were weighted in mass mixed together to make the mortar. First, it was placed the cement, sand and a portion of the admixture dissolved in water. The other part of the admixture was added after two minutes of mixing.

There was a differential treatment for admixtures Rhodapex LESS S and Rhodapex CO 436. The first one has a high viscosity, which hinders its dissolution in water and it is difficult to handle. The second one releases toxic gases during mixing, so the use of gloves and masks during preparation is necessary. All mixtures followed the recommendation of the literature on the use of air-entraining admixtures. The admixture dissolved in water was added during the mixing of the mortar.

Cubic, cylindrical and plate specimens were molded. The cubic specimens were used for the water immersion test. The cylindrical specimens were used for compressive strength and water absorption tests. The plate specimens were used for water permeability test.

Table II shows the different mixing times of mixtures to obtain the workability necessary to mold the specimens.

TABLE II: ThE MiXING TIME OF MiXTURES

\begin{tabular}{lc}
\hline & Mixing time $(\mathrm{min})$ \\
\hline Mixture 1 & 12 \\
\hline Mixture 2 & 16 \\
\hline Mixture 3 & 18 \\
\hline Mixture 4 & 9 \\
\hline Mixture 5 & 7 \\
\hline Mixture 6 & 9 \\
\hline Mixture 7 & 9 \\
\hline \hline
\end{tabular}

\section{Methods}

1) Compressive strength

The compressive strength tests were performed on cylindrical specimens with dimensions $50 \mathrm{~mm}$ diameter $\mathrm{x}$ 100mm height (Fig. 1) [18].

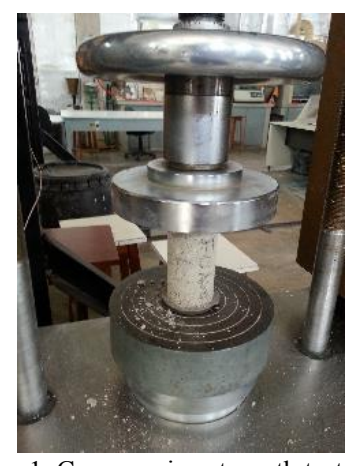

Fig. 1. Compressive strength test.

\section{Water Absorption by Immersion}

The water absorption by immersion measured the total volume of pores in the cellular concrete [19]. It was used a cubic specimen with edges of $50 \mathrm{~mm}$. The cube was obtained by cutting the prismatic specimens of size $300 \mathrm{~mm} \times 300 \mathrm{~mm} \mathrm{x}$ $50 \mathrm{~mm}$. They were placed in a kiln for 24 hours at $100^{\circ} \mathrm{C}$. After this period, they were weighed and immersed in water, where they stayed for a period of $24 \mathrm{~h}$. Then, they were removed from the water, dried with a damp cloth and weighted again. The difference of mass is the absorbed water.

\section{E. Water Absorption by Capillary Rise}

The water absorption by capillary rise test measured the capacity of water to penetrate into the cellular concrete [20]. Cylindrical specimens with dimensions $50 \mathrm{~mm} \times 100 \mathrm{mmm}$ were used. They stayed in a kiln for 24 hours at a temperature of $35^{\circ} \mathrm{C}$. After this step, they were cooled and a layer of waterproofing was applied in the lateral surface area. After the waterproofing resin has dried, the specimens were placed 
in a container with metal bracket in the bottom, which purpose is to prevent contact between the specimens and the bottom of the container. Finally, they were immersed in a constant water level, about $5 \mathrm{~mm}$ above the bottom face in contact with water (Fig. 2). The specimens were weighted after 5, 10, 15, 30, 60, 120, 240, 360, 480 and 1440 minutes. The water absorption by capillarity was calculated by the mass divided by the cross sectional area in contact with water.

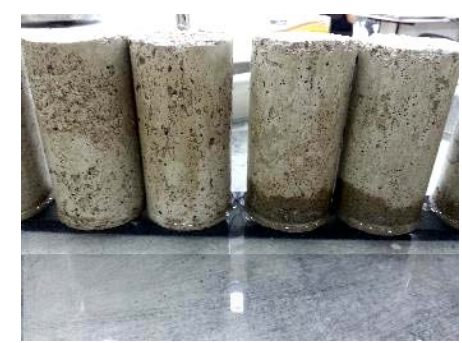

Fig. 2. Water absorption by capillarity test.

\section{F. Water Permeability of the Plates}

The water permeability test measured the ability of water flow through the plates. For this test, prismatic specimens were molded, which were in a kiln for 24 hours at $100{ }^{\circ} \mathrm{C}$. After this period, a PVC tube with dimensions $50 \mathrm{~mm}$ diameter $x 300 \mathrm{~mm}$ height was fixed orthogonally to the plate with a waterproof wax (Fig. 3). Therefore, it was possible to fill the PVC tube with water and analyze the behavior of each plate and its permeability.

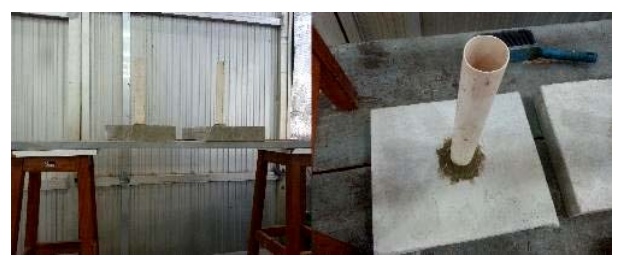

Fig. 3. Water permeability of the plates.

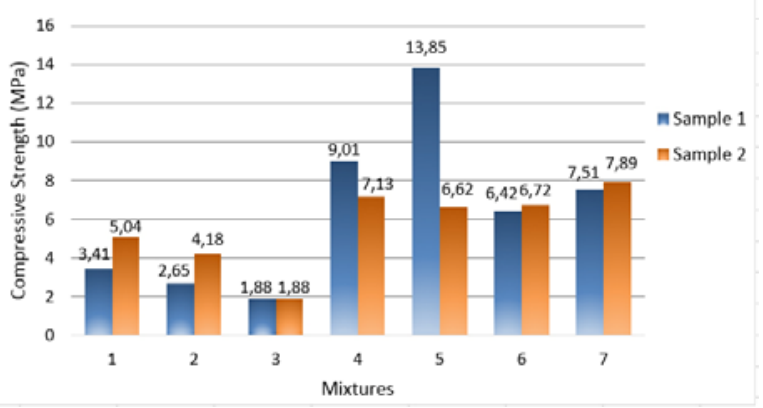

Fig. 4. Compressive strength results.

\section{RESULTS AND DISCUSSIONS}

\section{A. Compressive Strength}

The mixture 5 was more resistant (Fig. 4). The TecFill admixture was used. The mixture 3 had the lowest strength, in which the admixture TecFoam and $20 \mathrm{~g}$ of detergent were used.

The results of the mixtures 1, 2, 4 and 5 showed some discrepancies. This can be explained by the difficulty when molding the test samples or improper healing.
According to Zaidi et al., [21], the compressive strength should range from 1 to $15 \mathrm{MPa}$. Compared with the results obtained from this experimental work, the cellular concrete has a compressive strength in the range of values found in the literature.

\section{B. Water Absorption by Immersion}

In this test, it was noticed that the mixture 3 had the highest water absorption, in contrast to the mixture 5, with the lowest absorption (Fig. 5). The levels of mixtures 1, 2, 6 and 7 were good, with little difference between them. In an analysis of mixtures 2 and 7, both containing admixture Rhodapex LESS $\mathrm{S}$, it was observed that, doubling the amount of admixture and increasing by $45 \%$ the amount of water, the absorption by immersion varied slightly. Thus, the mixture 2 is more advantageous in respect of economy admixtures and water.

In mixtures 1 and 4, which used the TecFoam, the decrease of $33 \%$ in admixture and the increase of $45 \%$ in water diminished the absorption by immersion. The mixture 3 , which used the same admixture of mixtures 1 and 4, showed higher absorption by immersion by its larger mixing time and by a good mix design.

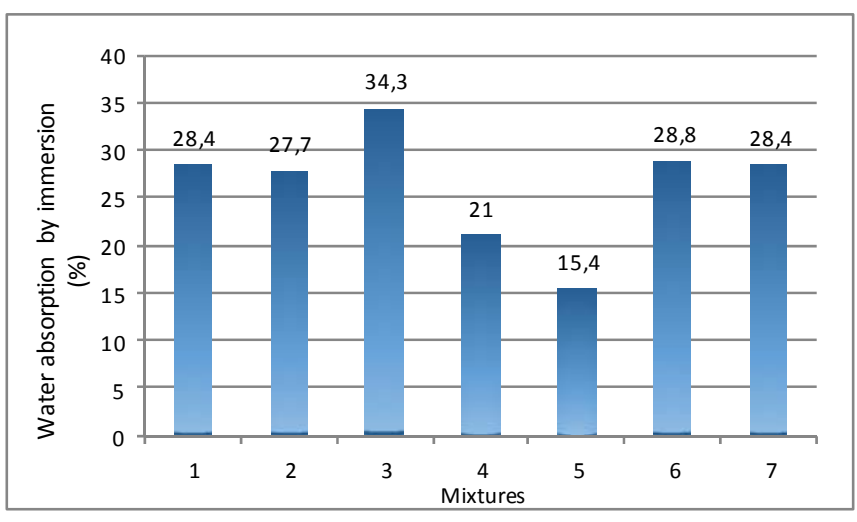

Fig. 5. Results of water absorption by immersion.

\section{Water Absorption by Capillarity and Capillary Rise}

The mixture 2 had the highest capillary water absorption (Fig. 6) and capillary rise (Table III). In mixture 5, lower values were observed. Correlating resistance with porosity, we could see the mixture 5 had a higher compressive strength and lower capillary water absorption.

TABLE III: THE HEIGHT OF CAPILLARY RISE

\begin{tabular}{cc}
\hline & The height of capillary rise $(\mathrm{cm})$ \\
\hline Mixture 1 & 5.25 \\
\hline Mixture 2 & 7.88 \\
\hline Mixture 3 & 4.58 \\
\hline Mixture 4 & 1.50 \\
\hline Mixture 5 & 0.60 \\
\hline Mixture 6 & 3.80 \\
\hline Mixture 7 & 3.05 \\
\hline \hline
\end{tabular}

In the case of mixture 2 , it had the lowest compressive strength and the highest capillary absorption (Fig. 7). As porosity and resistance are inversely proportional, it was expected the mixture 2 had the lowest compressive strength but it happened with mixture 3 . This performance can be explained by the fact that the mixture 3 had detergent in its composition, which may have weakened the cellular concrete 
without interfering significantly in the quantity and form of the pores.

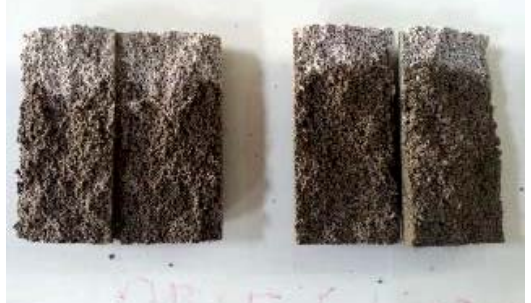

Fig. 6. Mixture 2 specimens after capillary water absorption test.

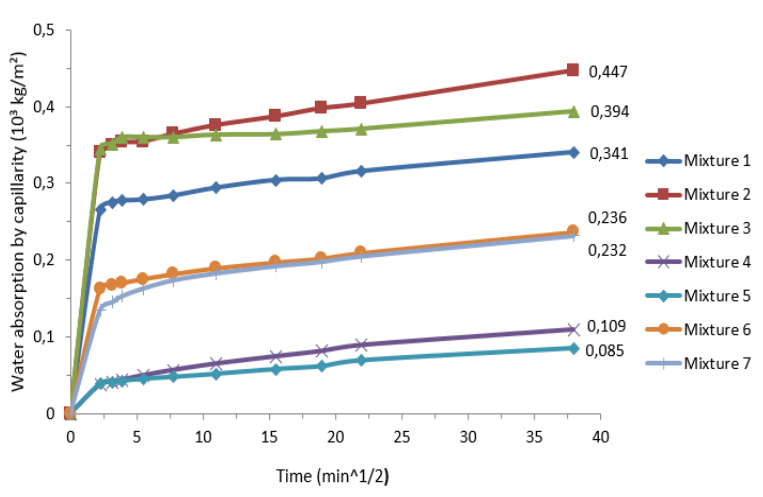

Fig. 7. Capillary water absorption with square root of time.

The mixtures with the lowest results of capillary rise are 4 , 5, 6 and 7 (Fig. 8). These four mixtures were prepared with $1.6 \mathrm{~L}$ of water in their mix design. Thus, the increase of the water of those four mixtures led to a decrease in the number of pores. This is the reason mixture 1, 2 and 3 showed higher water absorption by capillarity (Fig 9).

Paula et al. [22] found higher values of water absorption by capillarity using another kind of admixtures. She found $700 \mathrm{~kg} / \mathrm{m}^{2}$ using SK 100 Centripor and $600 \mathrm{~kg} / \mathrm{m}^{2}$ using the admixture Air Centrament 202.

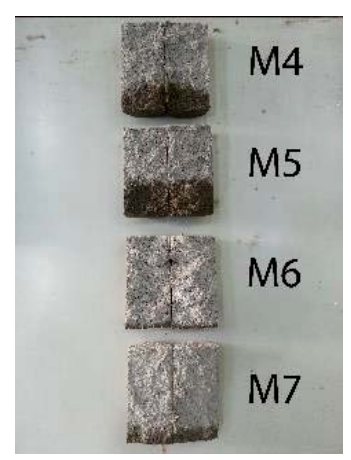

Fig. 8. Capillary rise of the Mixtures 4, 5, 6 and 7.

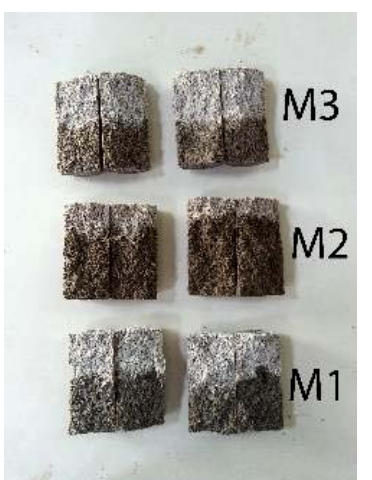

Fig. 9. Capillary rise of the mixtures 1,2 and 3.

\section{Water Permeability of the Plates}

Mixtures 1, 2 (Fig. 10) and 3 (Fig. 11) showed good results in this test. They allow the continuous and rapid flow of water in the form of drops and fillets. It is also possible to see that there were both horizontal and vertical percolation.

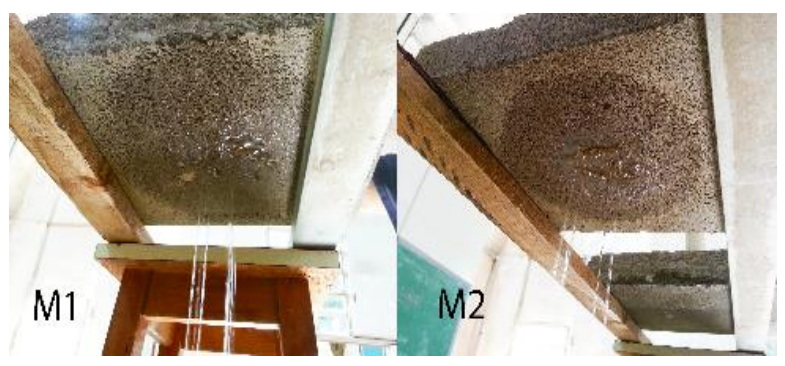

Fig. 10. Permeability test for Mixtures 1 and 2.

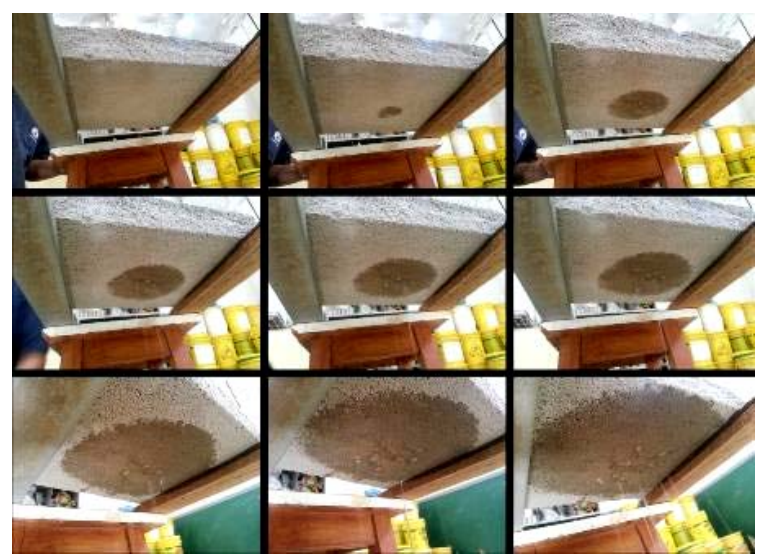

Fig. 11. Sequence of the water flow in plates for the Mixture 3.

The water did not flow any direction for the plates with the mixture 4, which indicates low porosity and few interconnected pores. As the water could not flow, it is concluded this mixture is not viable for the purpose of this research.

The mixture 5 had only a few drops of water flowing through it (Fig. 12). No horizontal percolation was observed on the plate, only vertical percolation. For the production of filters, it is essential that the water head horizontal and vertical paths. It cannot be observed in this mixture.

Mixture 6 showed the rapid and continuous flow of water in the form of fillets and drops. However, there was a lower horizontal percolation of water and an emergence of water out of the plate (Fig. 13).

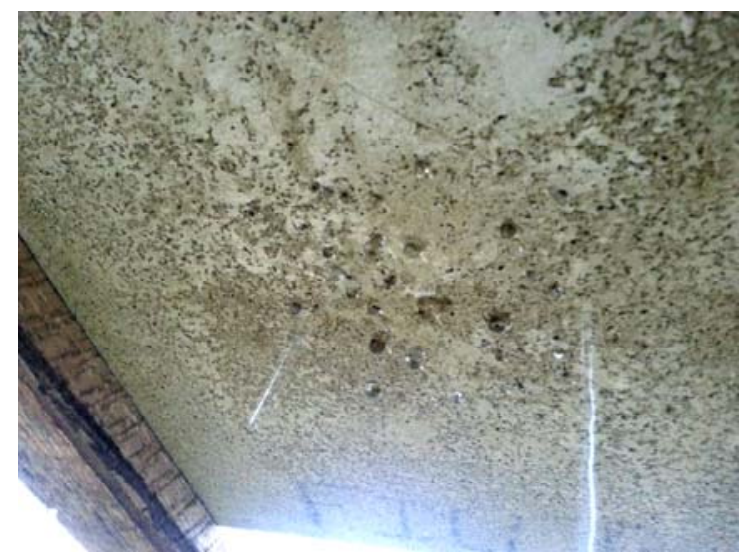

Fig. 12. Water permeability test of the plates with the Mixture 5 . 


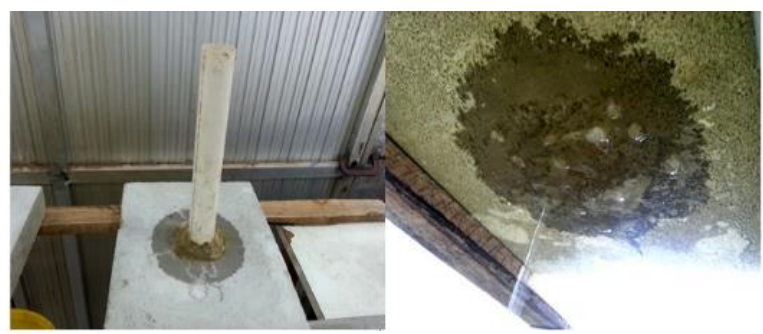

Fig. 13. Water permeability test of the plates with the Mixture 6.

In plates made with Mixture 7 the water did not flow and it rose out to their surface. On the opposite side, there were only a few drops (Fig. 14). The horizontal and vertical percolation were small, indicating few interconnected pores, what is unfeasible for the purpose of this study.

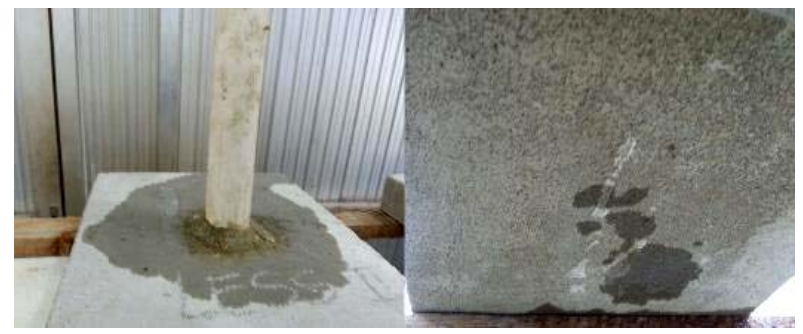

Fig. 14. Water permeability test of the plates with the Mixture 7.

\section{CONCLUSION}

From the experimental results, we observed that mixtures 4, 5 and 7 are discarded, since they did not present appropriate behavior for the production of plates to be used for filtering water. In these three mixtures, the water/binder ratio was higher, contributing to workability during molding. Nevertheless, it produced the pores in small quantities and they are not interconnected. Furthermore, the mixing time was shorter compared to mixtures 1, 2 and 3 .

Mixture 6 showed reasonable behavior in most of the tests. One difficulty is the preparation of the mixture since the admixture liberates toxic gases when it is in contact with the cement and water. Therefore, it was necessary to use gloves and protective masks for handling. So, it was also discarded.

The mixture 3 had good results of water permeability in the most of the test (34.3\% of water absorption). However, the low strength $(1.88 \mathrm{MPa})$ is a problem in the filter production, besides the difficulty of transportation and handling, since plate fracture occurs easily.

Mixtures 1 and 2 showed very similar behavior for water absorption by immersion and for water permeability. The difference was in the compressive strength: mixture 2 had 4.18 $\mathrm{MPa}$ and mixture 1 had 5.04 MPa. In contrast, in the test of capillary water absorption mixture 2 had better results with $447 \mathrm{~kg} / \mathrm{m}^{2}$, while mixture 1 presented $341 \mathrm{~kg} / \mathrm{m}^{2}$. Therefore, the two mixtures showed satisfactory results that achieved the project goal.

\section{ACKNOWLEDGEMENT}

The authors thank Dr. Carlos Eduardo Marmorato Gomes for the Rhodapex admixtures supply. The authors thank Grace Company for the Rheoset admixtures supply. The authors are grateful for the Laboratory of Binders and Wastes where the tests took place.

\section{REFERENCES}

[1] S. Chandra and L. Berntsson, Lightweight Aggregate Concrete Science, Technology and Applications, Delhi, India: Standard Publishers Distributors, 2003.

[2] K. A. Allende, I. M. Freitas, and F. A. I. Darwish, "Efeito da adição de areia e rejeito plástico no comportamento mecânico e na microestrutura do concreto celular," IN: $8^{\circ}$ Congresso Iberoamericano de Engenharia Mecânica, Cusco, Out. 23-25, 2007.

[3] N. Narayanan and K. Ramamurthy, "Structure and properties of aerated concrete," A Review. Cement and Concrete Composites, Amsterdam, vol. 22, no. 5, pp. 321-329, 2000.

[4] F. J. T. Filho, "Considerações sobre algumas propriedades dos concretos celulares espumosos," M.S. thesis, The School of Engineering of the University of São Paulo, São Paulo, 1992.

[5] L. A. Legatski, Cellular Concrete, STP169-C, Significance of Test and Properties of Concrete - Manquing Materials - ASTM Publications Code Number, 1994, pp. 533-539.

[6] J. A. Rossignolo, M. V. C. Agnesini, and J. A. Morais, "Properties of high performance LWAC for precast structures with Brasilian lightweight aggregates," Cement and Concrete Composite, no. 25, 2003, pp. 77-82.

[7] A. M. Neville, Properties of Concrete, 4th Ed. Essex, England: Pearson Education Limited, 2002.

[8] A. G. Loudon, "The thermal properties of lightweight concretes," Int J Lightweight Concrete, 1979, vol. 11, no. 2, pp. 71-85.

[9] R. Demirboga and R. Gul, "Thermal conductivity and compressive strength of expanded perlite aggregate concrete with mineral admixtures," Energy Build, 2003, vol. 35, pp. 1155-1159.

[10] X. Liu, K. S. Chia, and M. H. Zhang, "Development of lightweight concrete with high resistance to water and chloride-ion penetration," Cem Concr Compos, 2010, vol. 32, pp. 757-66.

[11] O. A. R. Ferreira, "Concretos leves: O concreto celular espumoso," $A$ Construção, no. 249, 1987.

[12] I. M. Freitas, K. A. Allende, and F. A. I. Darwish, "Otimização Da produção e das propriedades do concreto celular espumoso orgânico e inorgânico com adição de cinasita e rejeito plástico,” Xxiv Enegep, Florianópolis, SC, Brasil, , 2004.

[13] I. M. Freitas K. A. Allende, and F. A. I. Darwish, "Cellular foam concrete containing expanded clay and natural sand," II Simpósio Internacional sobre Concretos Especiais, Sobral, CE. Brasil, Proceedings on CD ROM, 2004.

[14] ABNT NBR 7211, Aggregates for Concrete, Rio de Janeiro, 2005.

[15] ABNT NBR NM 248 Aggregates - Sieve Analysis of Fine and Coarse Aggregates, Rio de Janeiro, 2003.

[16] ABNT NBR 9776, Aggregates - Determination of Fine Aggregate Specific Gravity by CHAPMAN Vessel - Method Test, Rio de Janeiro, 1988.

[17] ABNT NBR NM 45, Aggregates - Determination of the Unit Weight and Air-Void Contents, Rio de Janeiro, 2012.

[18] ABNT NBR 13279, Mortars Applied on Walls and Ceilings Determination of the Flexural and the Compressive Strength in the Hardened Stage, Rio de Janeiro, 2005.

[19] ABNT NBR 9778, Hardened Mortar and Concrete - Determination of Absorption, Voids and Specific gravity, Rio de Janeiro, 2009.

[20] ABNT NBR 15259, Mortars Applied on Walls and Ceilings Determination of Water Absorption Coefficient Due to Capillary action, Rio de Janeiro, 2005.

[21] A. A. M. Zaidi, A. I. Rahman, and N. H. A. Zaidi, "Behavior of fiber reinforced foamed concrete: indentation test analysis," in Proc. the Seminar on Geotechnical Engineering, University Tun Hussein Onn Malaysia, Johore, Malaysia, Dec. 27-27, 2008, pp. 92-101

[22] N. C. Paula and G. Camarini, "Avaliação das propriedades do concreto celular espumoso para uso em filtros de água," Congresso Interno de Iniciação Científica da Unicamp, pp. 405-406, 2012.

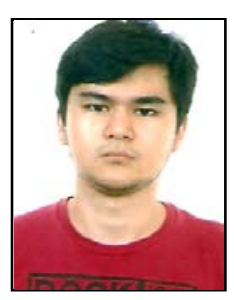

Renato César Maruyama was born at Mirandópolis, São Paulo, Brazil on January 23, 1993. He is currently a student of civil engineering at State University of Campinas, UNICAMP, São Paulo, Brazil. He is going to graduate at the end of 2016 .

$\mathrm{He}$ is interested in the field of civil engineering materials. His current research is focused on cellular concrete for filtering water. São Paulo Research Foundation, FAPESP supports his research project. 


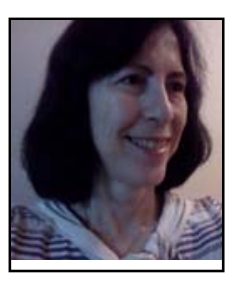

Gladis Camarini is a civil engineer and a professor at School of Civil Engineering, Architecture and Urban Design, University of Campinas. She had her master degree in 1988 and $\mathrm{PhD}$. degree in 1995 at University of São Paulo. She did postdoctoral studies at the Laboratoire des Materiaux et Durabilité des Constructions (LMDC) at Institut National des Sciences Apliquées (INSA, Toulouse, France, 1998) She also did postdoctoral studies at the National Institute for Space Research (INPE, São José dos Campos, Brazil, 2008).
Then she also did postdoctoral studies at the Institute of Science and Technology del Hormigón (ICITECH), the Polytechnic School of Valencia (UPV) (Valencia, Spain, 2012). She is a peer-reviewer of scientific journals indexed on the Journal Citation Reports, national and international journals, Congress and Seminars, and Brazilian Research Foundations. She is an IACSIT senior member. Her research interests include building materials, mineral binders, mortars, industrial and construction wastes, reusing and recycling of materials, mortar, concrete, and other composites. 